\title{
Sugarcane leaf area estimate obtained from the corrected Normalized Difference Vegetation Index (NDVI) ${ }^{1}$
}

\author{
Rodrigo Moura Pereira ${ }^{2}$, Derblai Casaroli ${ }^{2}$, \\ Lucas Melo Vellame ${ }^{3}$, José Alves Júnior ${ }^{2}$, Adão Wagner Pêgo Evangelista ${ }^{2}$
}

\section{ABSTRACT}

Large farmland areas and the knowledge on the interaction between solar radiation and vegetation canopies have increased the use of data from orbital remote sensors in sugarcane monitoring. However, the constituents of the atmosphere affect the reflectance values obtained by imaging sensors. This study aimed at improving a sugarcane Leaf Area Index (LAI) estimation model, concerning the Normalized Difference Vegetation Index (NDVI) subjected to atmospheric correction. The model generated by the NDVI with atmospheric correction showed the best results $\left(\mathrm{R}^{2}=0.84\right.$; $\mathrm{d}=0.95$; $\mathrm{MAE}=0.44$; RMSE $=0.55)$, in relation to the other models compared. LAI estimation with this model, during the sugarcane plant cycle, reached a maximum of 4.8 at the vegetative growth phase and 2.3 at the end of the maturation phase. Thus, the use of atmospheric correction to estimate the sugarcane LAI is recommended, since this procedure increases the correlations between the LAI estimated by image and by plant parameters.

KEY-WORDS: Saccharum spp.; vegetal growth; image analysis.

\section{INTRODUCTION}

In the 2014/2015 crop season, Brazil had nine million hectares planted with sugarcane (Saccharum spp.). The Goiás State has the third largest area planted in the country, estimated at 896,000 hectares for the 2014/2015 season (Conab 2014, IBGE 2015). In addition, products such as sugar and alcohol make sugarcane one of the main crops in Brazil.

Studies on sugarcane leaf area are important because this trait correlates with growth rates, since most of the essential carbohydrates are produced in the

\section{RESUMO}

Estimativa da área foliar de cana-de-açúcar a partir do índice de vegetação por diferença normalizada (NDVI) corrigido

As grandes extensões de terras cultivadas e o entendimento da interação da radiação solar com os dosséis vegetativos têm viabilizado a utilização dos dados de sensores remotos orbitais no monitoramento da cana-de-açúcar. Entretanto, os efeitos atenuantes atmosféricos interferem nos dados de refletância obtidos pelo sensoriamento remoto óptico. Objetivou-se calibrar um modelo de estimativa do Índice de Área Foliar (IAF) da cana-de-açúcar, em função do índice de vegetação por diferença normalizada (NDVI) submetido a correção atmosférica. O modelo gerado pelo NDVI corrigido apresentou os melhores resultados $\left(R^{2}=0,84 ; d=0,95\right.$; $\mathrm{MAE}=0,44 ; \mathrm{RMSE}=0,55)$, em relação aos modelos comparados. A estimativa do IAF com esse modelo, durante o ciclo de canaplanta, obteve um máximo de 4,8 na fase de crescimento vegetativo e 2,3 ao final da maturação. Assim, recomenda-se a aplicação de correção atmosférica para a estimativa do IAF da cana-de-açúcar, uma vez que tal procedimento aproxima o IAF estimado por imagem daquele estimado por parâmetros da planta.

PALAVRAS-CHAVE: Saccharum spp.; crescimento vegetal; processamento de imagem.

leaf. Leaves are directly responsible for solar energy absorption and conversion into chemical energy from photosynthesis. The intercepted light fraction is determined by the Leaf Area Index (LAI = leaf area/ soil area) (Watson 1947), which varies significantly in each sugarcane development stage (Almeida et al. 2008), especially due to accumulated degreedays (Teruel et al. 1997). Moreover, there is spatial and environmental variation in growth (Scarpari \& Beauclair 2008).

Taking into account the importance of leaf area in monitoring agricultural crops, such as sugarcane

1. Manuscript received in Jan./2016 and accepted for publication in May./2016 (http://dx.doi.org/10.1590/1983-40632016v4639303).

2. Universidade Federal de Goiás, Escola de Agronomia, Goiânia, GO, Brazil. E-mails: rodrigomoura@agricola.eng.br, derblaicasaroli@yahoo.com.br, josealvesufg@yahoo.com.br, awpego@bol.com.br.

3. Universidade Federal do Recôncavo da Bahia, Centro de Ciências Agrárias, Ambientais e Biológicas, Cruz das Almas, BA, Brazil. E-mail: lucasvellame@gmail.com. 
and its vast extensions of cultivated land, satellite images studies have been gaining ground, especially those that estimate vegetation index. However, there is a lack of information on the correlation between development stages and vegetation indexes for the determination of appropriate and specific managements in each period throughout the crop cycle. In addition, there is also a lack of information regarding yield estimations, which is related to plant dry matter increase. Plant dry matter can be detected by vegetation density, vegetation cover, biomass and leaf area index (Liu 2007).

Images from Landsat sensors proved to be potential for sugarcane monitoring in South and Central Brazil (Rudorff et al. 2010, Schultz et al. 2015). This is mainly because sugarcane is semiperennial and covers large and often contiguous areas, allowing spectral data to accurately estimate leaf area in $30 \mathrm{~m}$ pixels (Giongo et al. 2010). However, the relationship between sunlight reflectance and canopy architecture affects the optical properties of sugarcane. Differences in the canopy architecture affect reflectance. For example, planophile (medium erect foliage) produces higher reflectance than erectophile (erect foliage) in sugarcane plants (Galvão et al. 2006).

Some studies have shown different plant growth patterns depending on the remote sensing estimation technique (Turner et al. 1999, Colombo et al. 2003). One of these techniques is the Normalized Difference Vegetation Index (NDVI), which is determined by the ratio between the difference and the sum of reflectance in the visible (VIS) and near-infrared (NIR) bands (Wiegand et al. 1991). NDVI associates the electromagnetic radiation portion related to biomass amount (NIR) and the electromagnetic radiation portion related to plant photosynthetic pigments (VIS) activity (Jackson \& Huete 1991).

In Brazil, Rudorff \& Batista (1990) used satellite data from Landsat MSS (Landsat 4) and an agrometeorological model for yield prediction. The yield estimated by the vegetation index model alone or the agrometeorological model alone gave poor results, when compared to the combined (vegetation index and agrometeorological data) model. The authors suggested that atmospheric correction procedures should be used for more accurate sugarcane yield prediction models. Recently, some NDVI studies have been successfully used for sugarcane evaluations, such as area classification, varietal identification, disease detection and yield prediction (Apan et al. 2004, Galvão et al. 2006, Picoli et al. 2009, Rudorff et al. 2010).

The atmosphere interacts with electromagnetic radiation, interfering in the identification of ground targets captured by remote sensing images. Atmospheric scattering causes attenuation of the signal received by the satellite sensor and is present in all electromagnetic spectrum wavelengths, suggesting the necessity of correction of data derived from satellite images (Latorre et al. 2002).

This study aimed at calibrating a model to measure sugarcane LAI temporal variation through NDVI subjected to atmospheric correction, analyzing sugarcane crop LAI and phenologic data temporal variation obtained in the field and comparing the data obtained by the model applied in this study with the data recorded by other models that relate LAI and NDVI derived from satellite images.

\section{MATERIAL AND METHODS}

The experiment was conducted in a study area located in Santo Antônio de Goiás, Goiás State, Brazil, in the 2013/2014 crop season. According to Köppen, the climate of the region is classified as Aw (tropical Savannah/megathermal). Average annual air temperature was $23.0^{\circ} \mathrm{C}$. The minimum temperature was recorded in June $\left(14.4^{\circ} \mathrm{C}\right)$ and the maximum temperature was recorded in September $\left(31.7^{\circ} \mathrm{C}\right)$. Rain regime is well-defined, with one rainy (October to April) and one dry (May to September) season. Average annual rainfall is equal to $1,498 \mathrm{~mm}$ (Silva et al. 2014).

The experimental area (1.08 ha) corresponded to four three pixel windows of the image (Xavier \& Vetorazzi 2004). A previous analysis in the field showed leaf area homogeneity in the plant stand. The sugarcane variety grown in the study area was CTC-04, which is medium to late maturing and drought-tolerant (CTC 2013). Soil preparation was conducted with lime (4t ha-1) and gypsum $\left(2 \mathrm{t} \mathrm{ha}^{-1}\right)$ application. A semi-mechanized planting system with pre-sprouted seedlings was adopted. Topdressing was held in May/2013, at 30 days after planting (DAP), with NPK 08-28-16 fertilizer (510.28 $\mathrm{kg} \mathrm{ha}^{-1}$ ). Weed control was performed with applications of Aminol $2.4\left(0.16 \mathrm{~L} \mathrm{ha}^{-1}\right)$, Hinofix $\left(0.09 \mathrm{~L} \mathrm{ha}^{-1}\right)$, Callisto $\left(0.3 \mathrm{~L} \mathrm{ha}^{-1}\right)$ and Dual Gol (4.13 $\left.\mathrm{L} \mathrm{ha}^{-1}\right)$ at 36 DAP 
and Discover (3.62 L ha-1), Aurora (0.06 $\left.\mathrm{L} \mathrm{ha}^{-1}\right)$ and Ancosar (1.77 $\left.\mathrm{L} \mathrm{ha}^{-1}\right)$ at 207 DAP.

Meteorological data (air temperature, rainfall, relative humidity and daily insolation) were collected from automatic weather stations belonging to the Escola de Agronomia - Universidade Federal de Goiás, in Goiânia, and Embrapa Arroz e Feijão, in Santo Antônio de Goiás, located at $17 \mathrm{~km}$ and $7 \mathrm{~km}$ from the study area, respectively, both in the Goiás State, Brazil. In addition, a thermo-pluviometric station was installed in the studied area, at a distance of $100 \mathrm{~m}$ from the plots.

To avoid underestimation of NDVI values due to interference of bare soil reflectance in the correlation between spectral and field data (Montandon \& Small 2008), biometric indexes were evaluated in three tillers by three pixel windows. Three tillers could be obtained at the end of the stem growth and maturation phase, from January to August 2014 (281-506 DAP). The biometric traits evaluated were: i ) stem height (Silva et al. 2012); ii) number of tillers per $\mathrm{m}^{2}$ (Nassif et al. 2012); iii) number of green leaves, corresponding to the number of fully expanded green leaves capable of photosynthesis; iv) leaf area per tiller, which was estimated according to the equation proposed by Hermann \& Câmara (1999); v) Leaf Area Index (LAI, $\mathrm{m}^{2} \mathrm{~m}^{-2}$ ), which is the ratio between the leaf and the soil area (Nassif et al. 2012).

Sugarcane degree-days $\left(\mathrm{DD},{ }^{\circ} \mathrm{C}\right.$ day $\left.^{-1}\right)$ were estimated as proposed by Villa Nova et al. (1972), using the basal temperature of $18^{\circ} \mathrm{C}$ (Bachi \& Souza 1978). Following the methodology by Teruel et al. (1997), DD values were standardized for each day through the relation between photoperiod and the 12-hour period.

The spectral database was obtained through Landsat 8/OLI images from the Earth Explorer database. Selected images were taken between sugarcane planting (April/2013) and harvest (August/2014). These images consist of raster format (.tiff) digital files quantified in digital number or gray level values (DN), with acquisition interval of 16 days and spatial resolution of $30 \mathrm{~m}$. DN data were converted to top of atmosphere reflectance (TOA) by using radiometric rescaling coefficients provided in the metadata file that was made available along with images (USGS 2013).

Image preprocessing consisted of visual inspection to assess the quality of images regarding pre-established criteria, such as dark pixels occurrence, clouds incidence and the perfect identification of tillers cultivated with sugarcane. Correlations between spectral and biometric data were performed in ten dates that coincided with the satellite passage, between 281 and 506 DAP. After adjustment, the model with the best performance was applied to all images, from the planting season (26 DAP) to harvest (506 DAP), in order to observe the model behavior in LAI monitoring along a sugarcane production cycle (1.5 year).

Orbit/point 222/71 images dates were: 05/01/2013 (26 DAP), 05/17/2013 (42 DAP), 06/18/2013 (74 DAP), 07/04/2013 (90 DAP), 08/05/2013 (122 DAP), 08/21/2013 (138 DAP), 09/06/2013 (154 DAP), 10/24/2013 (202 DAP), 01/28/2014 (298 DAP), 04/02/2014 (362 DAP), 05/04/2014 (394 DAP), 05/20/2014 (410 DAP), 06/05/2014 (426 DAP), 06/21/2014 (442 DAP), 07/07/2014 (458 DAP), 07/23/2014 (474 DAP), 08/08/2014 (490 DAP) and 08/24/2014 (506 DAP).

Top of atmosphere reflectance (TOA) was estimated through red and near-infrared bands radiometric calibration, which made the conversion of image DN values to radiance possible (USGS 2013).

Atmospheric correction in TOA images was conducted to obtain the images termed as surface reflectance (SR). At this stage, the MODTRAN radioactive transfer model compiled to the FLAASH algorithm was used (Anderson et al. 2002). Fixed parameters used in the algorithm were the study area central coordinates $\left(16^{\circ} 28^{\prime} 54,30^{\prime \prime} \mathrm{S}\right.$; 49 $\left.20^{\circ} 57,36^{\prime \prime} \mathrm{W}\right)$, sensor altitude $(705 \mathrm{~km})$, average area elevation (769 m), pixel size (30 m), the Mid-Latitude Summer atmospheric model and the rural aerosol model. Estimated water vapor content in the atmosphere $\left(\mathrm{w}, \mathrm{g} \mathrm{cm}^{-2}\right)$ and vapor pressure of water $(\mathrm{kPa})$ were obtained according to Leckner and Tetens equations, which were detailed in studies by Iqbal (1983) and Pereira et al. (2002), respectively.

Through TOA and SR images, Normalized Difference Vegetation Index without atmospheric correction $\left(\mathrm{NDVI}_{\mathrm{AP}}\right)$ and Normalized Difference Vegetation Index with atmospheric correction $\left(\mathrm{NDVI}_{\mathrm{COR}}\right)$ index values were obtained. Red $(0.64-$ $0.67 \mu \mathrm{m})$ and near-infrared $(0.85-0.88 \mu \mathrm{m})$ bands reflectance data were extracted from pixel windows. Thus, NDVI was calculated by the following equation:

$$
\text { NDVI }=\frac{\rho \text { nir }- \text { pred }}{\rho \text { nir }+ \text { pred }}
$$


where $\rho$ nir is the near-infrared band reflectance and pred is the red band infrared reflectance. Two other methods were used to estimate LAI, based on NDVI: the method described by Picoli et al. (2009) and that described by Xavier \& Vetorazzi (2004).

In order to evaluate the methods used to obtain LAI, in terms of precision and accuracy, the following statistical indexes were used: a) Wilmott concordance index (1985) (d); maximum error $\left(\mathrm{E}_{\max }\right)$; mean absolute error (MAE); root-mean-square error (RMSE) and determination coefficient $\left(\mathrm{R}^{2}\right)$, as described by Camargo \& Sentelhas (1997).

\section{RESULTS AND DISCUSSION}

Growth analysis was performed in relation to the accumulated degree-days (ADD), and the crop response to thermal units required for its development was identified (Figures 1a, 1b and 1c). LAI increase was accentuated until 362 DAP or 1,184 ADD in the sugarcane, when LAI peaked at 5.4 (Figure 1a). From 1,184 ADD, a LAI decrease was observed, with an average value of 1.56 at $506 \mathrm{DAP}$ or 1,566 ADD. The largest LAI decrease period was observed between 410 and 426 DAP, at a rate of $-0.07 \mathrm{~m}^{2} \mathrm{~m}^{-2}$ day $^{-1}$.

Regarding plant height, growth rates were observed until 442 DAP or 1,424 ADD, with an average plant height of $3.86 \mathrm{~m}$ (Figure $1 \mathrm{~b}$ ). The highest average growth rate $\left(0.02 \mathrm{~m} \mathrm{day}^{-1}\right)$ was recorded in the period between 298 DAP (start of measurement) and $336 \mathrm{DAP}$. After this period, zero growth rates were observed from 442 DAP (in the maturation phase). In this period, sugarcane shows LAI stabilization (in plant cane), during which crop growth is quite slow due to sucrose accumulation, at the expense of stem elongation (Keating et al. 1999). The number of green leaves (NGL) had maximum and minimum values of 11 and 2 leaves per stem during the evaluation period. Moreover, an average NGL of 10 during leaf expansion was observed. Average NGL during the negative rates stage was 6.7 , and the lowest average value (3.48) was found in the last assessment, at 506 DAP, with 1,566 ADD (Figure 1c).

$\mathrm{NDVI}_{\mathrm{AP}}$ values ranged from 0.39 to 0.79 and $\mathrm{NDVI}_{\mathrm{COR}}$ values between 0.45 and 1 (Figure 2a), from 298 to 506 DAP, corresponding to the end of the stem growth phase and maturation, respectively. When comparing $\mathrm{NDVI}_{\mathrm{AP}}$ and $\mathrm{NDVI}_{\mathrm{COR}}$, it was observed that uncorrected values are lower than corrected values. Lower NDVI ${ }_{\mathrm{AP}}$ values occurred due to atmospheric attenuation caused by aerosols, water vapor and ozone vapor, which alter the actual values that should be recorded by the sensor. From the crop cycle, the period represented the sugarcane maturation phase, resulting in an expected reflectance reduction in the infrared band, with a consequent NDVI value reduction (Wiegand et al. 1991).

Through model analysis, it was possible to detect differences between $\mathrm{NDVI}_{\mathrm{AP}}$ and $\mathrm{NDVI}_{\mathrm{COR}}$ (Figure 2a), where NDVI ${ }_{\text {COR }}$ values were higher than $\mathrm{NDVI}_{\mathrm{AP}}$ in all evaluation periods, with relative errors between $11 \%$ and $43 \%$ (Figure $2 b$ ). Turner et al. (1999) reported that such gain should be expected, since the geometry between the sun, surface and sensor is different between images due to atmosphere optical property variation, which may cause noise in spectral relations. It was also found that the smallest relative errors were found in the period
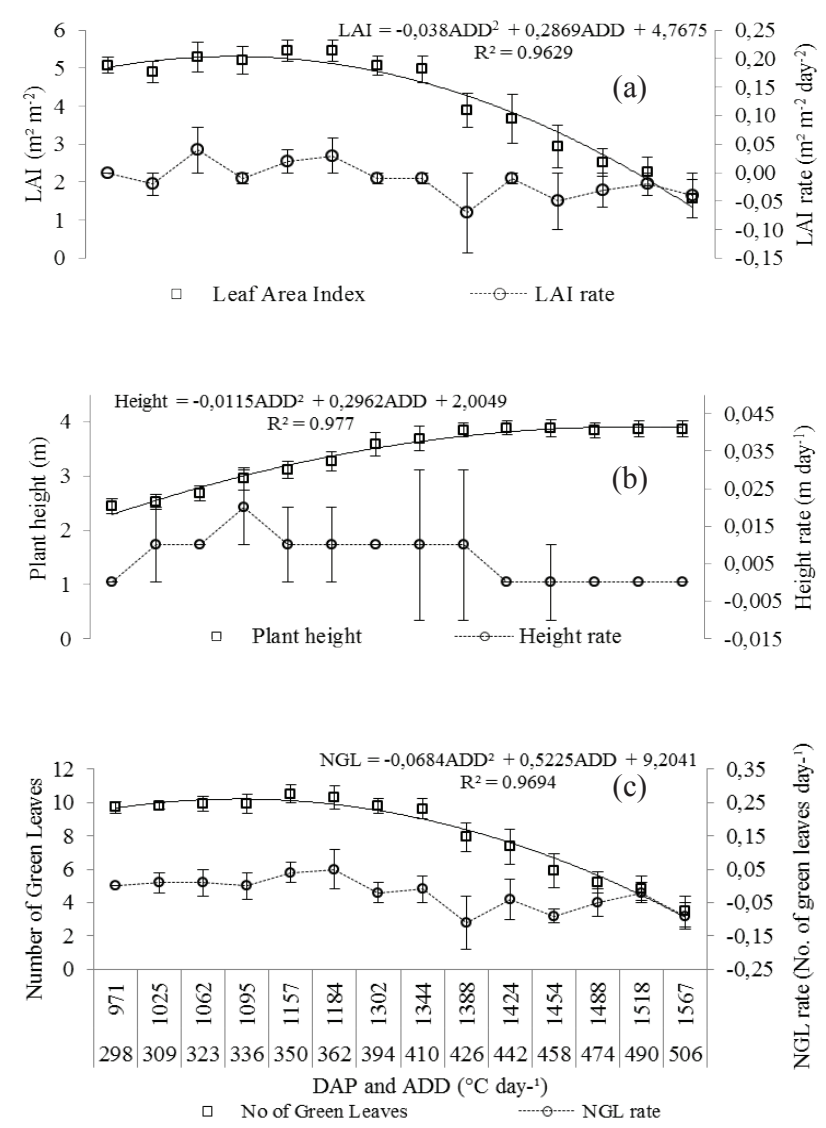

Figure 1. Temporal variation and respective rates with standard deviation of sugarcane leaf area index (a), plant height (b) and number of green leaves (c), in relation to accumulated degree-days (ADD), between 298 and 506 days after planting (DAP). 
next to sugarcane harvest, when it was observed that the tiller area in the pixels of the image was mostly formed by plant constituents (leaves, stems and straw), which resulted in NDVI values between 0.5 and 0.4 , at 506 DAP. The lowest NDVI values at that stage were closer when comparing images with and without atmospheric correction application, with lower relative errors observed (Figure $2 b$ ).

At the end of the sugarcane production cycle, average relative differences were of $15 \%$, confirming the results found by Agapiou et al. (2011), who evaluated the atmospheric correction effect in NDVI obtained by Landsat 7 ETM + images. They found that average relative differences are equal to $20 \%$ for NVDI $<0.40$, but are higher than $50 \%$ for NDVI $>0.40$ values.

In the relation between LAI and NDVI, there was higher data dispersion in the adjustment of LAI with $\mathrm{NDVI}_{\mathrm{AP}}\left(\mathrm{R}^{2}=0.60\right)$, when compared to the adjustment with $\mathrm{NDVI}_{\mathrm{COR}}\left(\mathrm{R}^{2}=0.84\right)$ (Figures $3 \mathrm{a}$ and $3 b)$. Thus, $\mathrm{NDVI}_{\mathrm{AP}}$ and $\mathrm{NDVI}_{\mathrm{COR}}$ saturation points were achieved with a value of approximately 0.80 and 1.0 , respectively, corresponding to a $\mathrm{LAI} \approx 5.4$ with both models.

Sugawara \& Rudorff (2011) observed high NDVI variability during sugarcane vegetative growth periods. Such variation decreases in final growth periods, when even with biomass increase NDVI is saturated close to 0.9 values. In other words, above this value, NDVI is not influenced by biomass growth.

It was found that the method that had the lowest dispersion in relation to a straight 1:1 (LAI:NDVI), determined by the " $d$ " index, was the LAI estimate with NDVI with atmospheric correction, which also had the lowest RMSE, EA max $_{\text {and }} \mathrm{EA}_{\text {med }}$ (Figure 4).
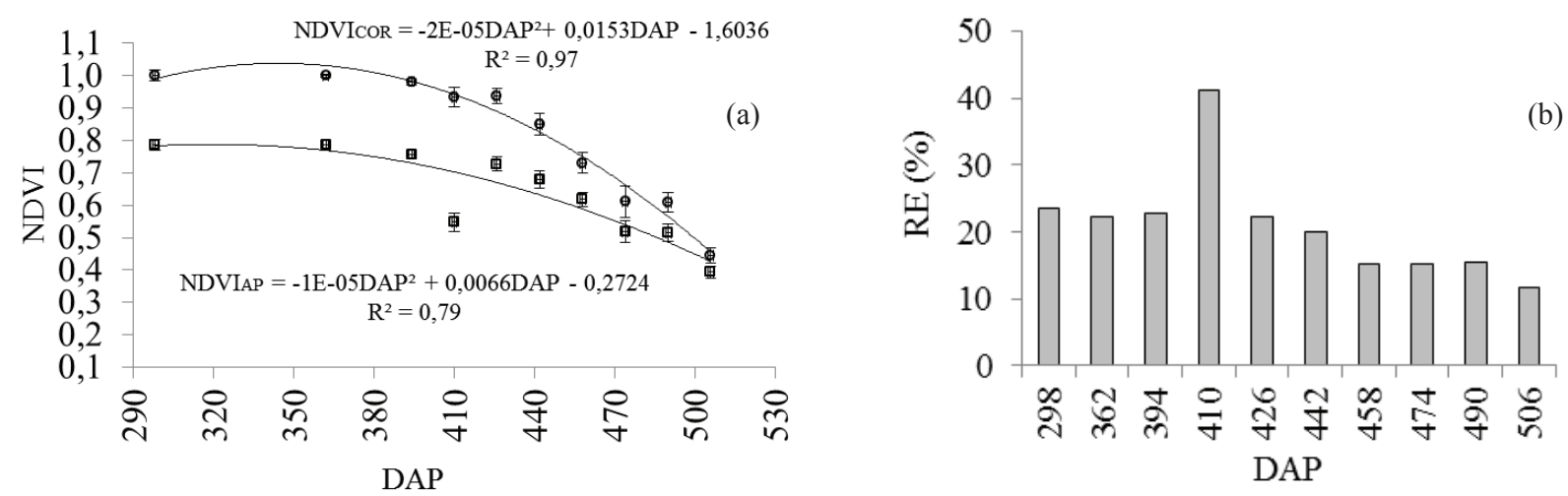

Figure 2. Models that related $\mathrm{NDVI}_{\mathrm{AP}}$ (without atmospheric correction) and $\mathrm{NDVI}_{\mathrm{COR}}$ (with atmospheric correction) obtained from Landsat 8 , in relation to days after sugarcane planting (DAP), with their respective standard deviations (a) and relative error (b) $\left[\mathrm{RE} \%=100 \cdot\left(\mathrm{NDVI}_{\mathrm{COR}}-\mathrm{NDVI}_{\mathrm{AP}}\right) / \mathrm{NDVI}_{\mathrm{COR}}\right]$.
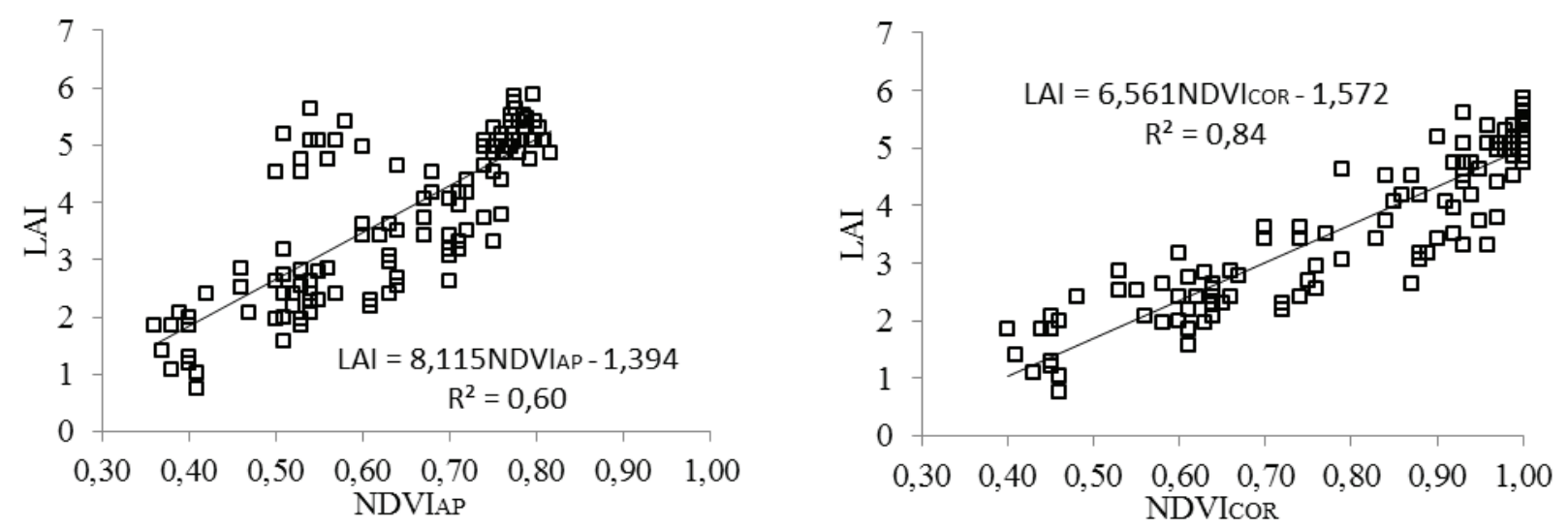

Figure 3. Sugarcane LAI estimation models from $\mathrm{NDVI}_{\mathrm{AP}}$ without atmospheric correction (a) and from corrected NDVI ${ }_{\mathrm{COR}}$ (b) obtained through the Landsat 8 satellite. 
The less satisfactory results were detected through the Picoli's methodology (Picoli et al. 2009). Such differences may reflect sugarcane canopy structural variation in plots, when compared to localized samples, suggesting the need for increased field sampling, in order to improve the accuracy of LAI predicted with spectral models. By analyzing values estimated by the Picoli et al. (2009) and Xavier \& Vetorazzi (2004) models, LAI values were mostly underestimated, when compared to the data estimated in the field. These models were obtained under different conditions, such as different sensors and resolutions between images, which may explain the lack of fit for the data obtained in this study.

$\mathrm{LAI}_{\mathrm{COR}}$ temporal evolution during the plant cane production cycle (Figure 5) shows that intraannual variability of plot mean $\mathrm{LAI}_{\mathrm{COR}}$ followed the sugarcane phenological development. In the interval between 26 and 138 DAP, a positive relation was observed to the NDVI of 0.42 , which resulted in a LAI $=1.98$ at the end of the tillering stage. During this period of initial growth ( $\sim$ months), cumulative rainfall was only $116.6 \mathrm{~mm}$. With rainfall increase and the beginning of the rainy season, at the end of the vegetative phase and early maturation, there was a NDVI increase, with the maximum value observed in January/2014 (NDVI $=1)$ at 298 DAP and a LAI of 4.81. Between the months of October/2013 and January/2014, few high-quality images could be obtained, as these are rainy season months, and, at this time, images have great cloud cover.

In the subsequent period, from 298 to 426 DAP (January to June/2014), it was possible to obtain images without cloud cover and the accumulated rainfall was $568.2 \mathrm{~mm}$, enough for NDVI to remain at levels close to 1 until the beginning of June/2014 (426 DAP; NDVI $=0.95 ;$ LAI $=4.49$ ). From June, with a sharp rainfall decrease and with plants already in the
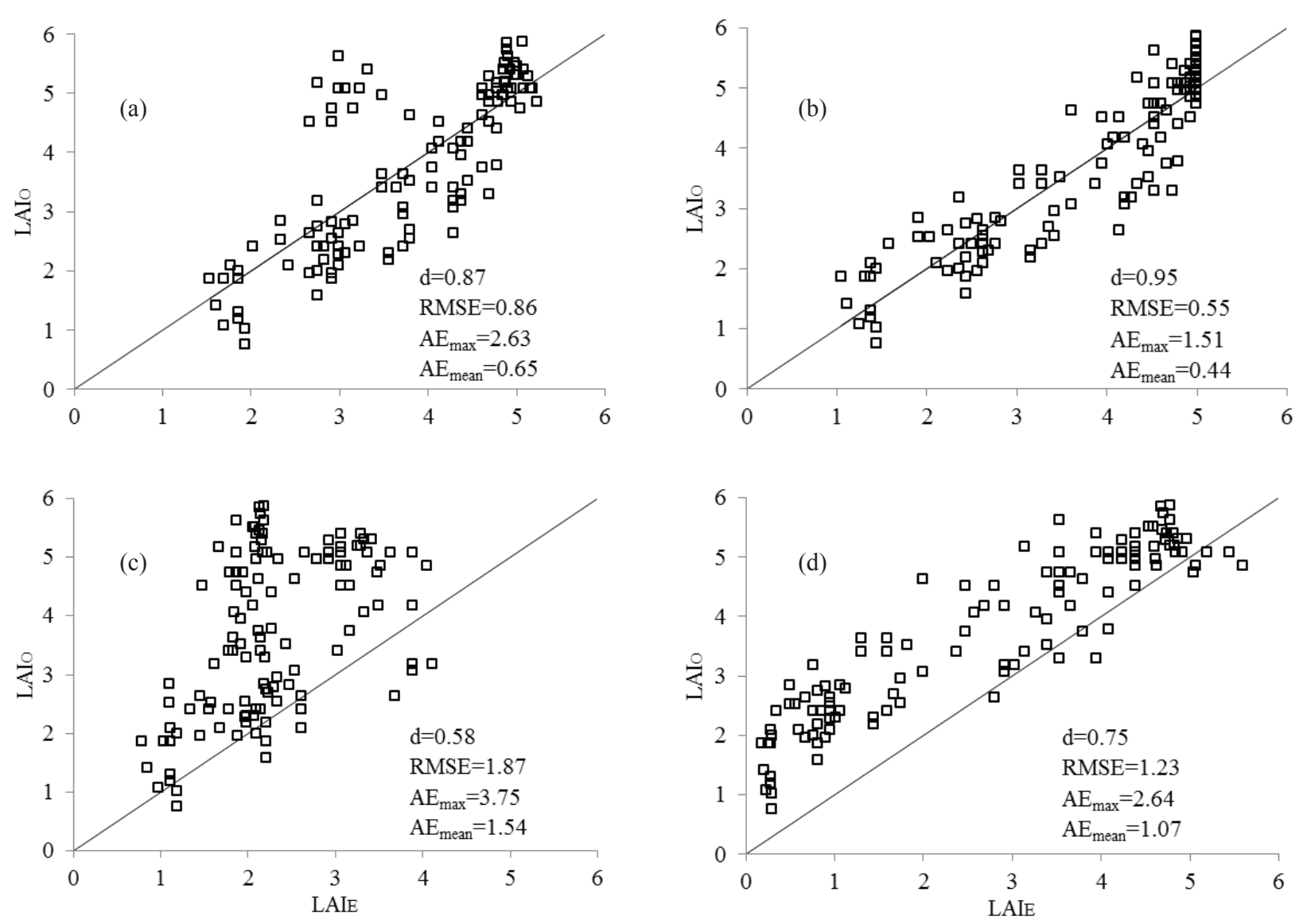

Figure 4. Relation between sugarcane Leaf Area Index estimated in the field $\left(\mathrm{LAI}_{\mathrm{O}}\right)$ and the indexes estimated $\left(\mathrm{LAI}_{\mathrm{E}}\right)$ by models obtained by NDVI without atmospheric correction $\left[\mathrm{NDVI}_{\mathrm{AP}}(\mathrm{a})\right]$, with atmospheric correction $\left[\mathrm{NDVI}_{\mathrm{COR}}(\mathrm{b})\right]$ and by Picoli et al. (2009) (c) and Xavier \& Vetorazzi (2004) (d), as well as their respective Wilmot's "d" index, root-mean-square error (RMSE), maximum absolute error $\left(\mathrm{AE}_{\max }\right)$ and mean absolute error $\left(\mathrm{AE}_{\text {mean }}\right)$. 


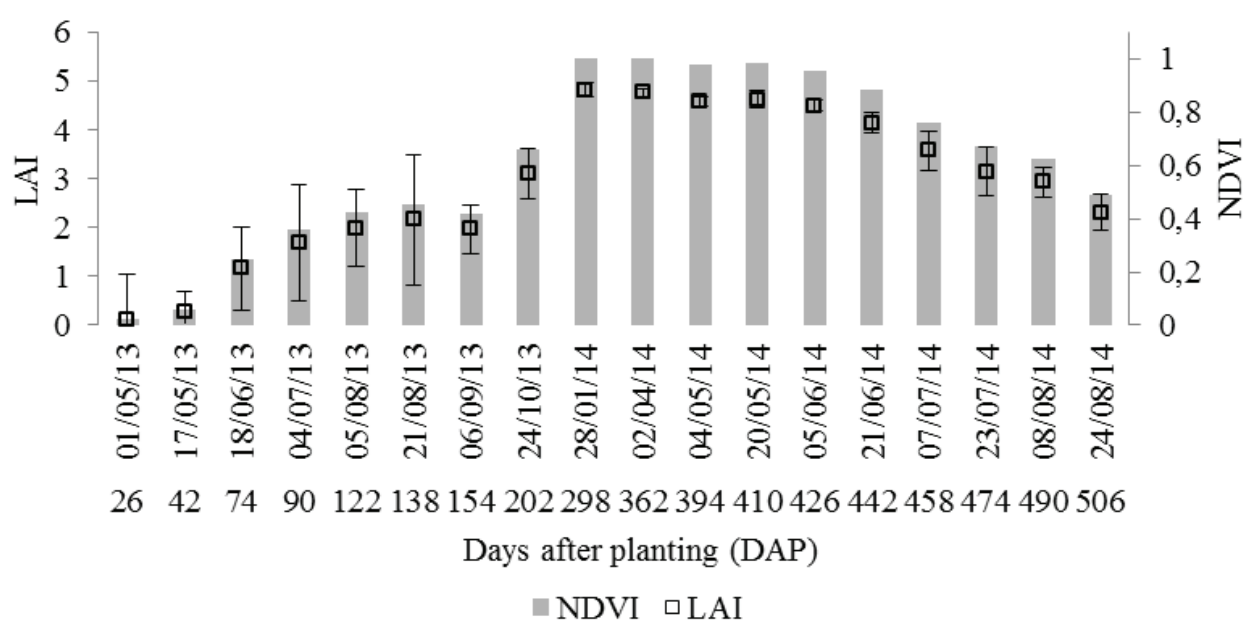

Figure 5. Temporal evolution of $\mathrm{NDVI}_{\mathrm{COR}}$ and spectral estimation of $\mathrm{LAI}_{\mathrm{COR}}$ with standard deviation, in relation to image acquisition dates and days after planting.

maturation phase, NDVI had a sharp drop. Clear sky conditions in this period allowed the acquisition of high-quality images between June and August/2014 and satisfactory estimation of LAI depletion. Thus, at the end of the production cycle, the NDVI of 0.49 in the image of 506 DAP, from August/2014, resulted in a LAI of 2.3.

The NDVI value increase is associated with biomass growth, which, in turn, is favored by high rainfall periods. Lucas \& Schuler (2007) observed that the maximum NDVI value of 0.6 occurred after a period of highest rainfall, and after a rainfall decrease from $585.2 \mathrm{~mm}$ to $25.9 \mathrm{~mm}$, NDVI began to decrease until the minimum of 0.27 . In relation to the crop cycle, authors found in a single image NDVI values of 0.4 in maturation phase plots and of 0.3 in newly harvested plots, where regrowth exerts little influence on spectral response and the large exposed soil area results in low NDVI values.

Sugawara \& Rudorff (2011) studied the NDVI obtained from MODIS/Terra data and observed a NDVI from 0 to 0.99 , between initial and maximum growth stages, in São Paulo State areas cultivated with sugarcane. In the region studied by the authors, harvest took place between April and September, during which there was a sharp drop in NDVI values from more than 0.75 to less than 0.4 , at the end of the harvest period. In addition, it was reported that, although sugarcane is harvested at different dates throughout the dry season, a post-harvest NDVI increase only occurs after the onset of the rainy season.
Currently, there is no general agreement on the critical spectral regions for agriculture and specifications for a dedicated orbital agricultural sensor. The effective use of NDVI requires that the complex interplay of atmospheric and canopy architecture constraints be simultaneously considered. Thus, selecting appropriate radiometric correction, as well as suitable processing techniques for extracting sugarcane spectral information, makes remotely sensed data useful for estimating sugarcane leaf area index with satisfactory results.

\section{CONCLUSIONS}

1.Atmospheric correction application is recommended in reflectance data to estimate the vegetation index NDVI, as it increases the quality of correlations between spectral data and surface.

2. Leaf Area Index temporal variation obtained from the corrected NDVI model is satisfactory, showing the growth, stabilization and decrease expected phases of a typical production cycle.

\section{REFERENCES}

AGAPIOU, A. et al. The importance of accounting for atmospheric effects in the application of NDVI and interpretation of satellite imagery supporting archaeological research: the case studies of Palaepaphos and Nea Paphos sites in Cyprus. Remote Sensing, v. 12, n. 3, p. 2605-2629, 2011. 
ALMEIDA, A. C. S. et al. Desenvolvimento vegetativo e produção de variedades de cana-de-açúcar em relação à disponibilidade hídrica e unidades térmicas. Ciência e Agrotecnologia, v. 32, n. 5, p. 1441-1448, 2008.

ANDERSON, G. P. et al. MODTRAN4-based atmospheric correction algorithm: FLAASH (fast lineof-sight atmospheric analysis of spectral hypercubes). In: ALGORITHMS AND TECHNOLOGIES FOR MULTISPECTRAL, HYPERSPECTRAL, AND ULTRASPECTRAL IMAGERY, 8., 2002, Orlando. Proceedings... Orlando: Society of Photo Optics, 2002. p. 65-71.

APAN, A. et al. Detection of sugarcane 'orange rust' disease using EO-1 Hyperion hyperspectral imagery. International Journal of Remote Sensing, v. 25, n. 2, p. 489-498, 2004.

BACHI, O. O. S.; SOUZA, J. A. G. C. Minimum threshold temperature for sugar cane growth. In: INTERNATIONAL SOCIETY OF SUGARCANE TECHNOLOGISTS, 2., 1978, São Paulo. Proceedings... São Paulo: Impress, 1978. p. 1733-1741.

CAMARGO, A. P.; SENTElHAS, P. C. Avaliação do desempenho de diferentes métodos de estimativas da evapotranspiração potencial no Estado de São Paulo, Brasil. Revista Brasileira de Agrometeorologia, v. 5, n. 1, p. 89-97, 1997.

CENTRO DE TECNOLOGIA CANAVIEIRA (CTC). Revista variedades CTC. 2013. Available at: $<\mathrm{http}: / / \mathrm{www}$. ctcanavieira.com.br>. Acess on: 10 Dec. 2013.

COLOMBO, R. et al. Retrieval of leaf area index in different vegetation types using high resolution satellite data. Remote Sensing of Environment, v. 86, n. 1, p. 120131, 2003.

COMPANHIA NACIONAL DE ABASTECIMENTO (Conab). Acompanhamento da safra brasileira de cana-deaçúcar: safra 2014/15. 2014. Available at: <www.conab. gov.br>. Acess on: 04 Apr. 2015.

GALVÃO, L. S.; FORMAGGIO, A. R.; TISOT, D. A. The influence of spectral resolution on discriminating Brazilian sugarcane varieties. International Journal of Remote Sensing, v. 27, n. 4, p. 769-777, 2006.

GIONGO, P. R. et al. Albedo à superfície a partir de imagens Landsat 5 em áreas de cana-de-açúcar e Cerrado. Revista Brasileira de Engenharia Agrícola e Ambiental, v. 14, n. 3, p. 279-287, 2010.

HERMANN, E. R.; CÂMARA, G. M. S. Um método simples para estimar a área foliar de cana-de-açúcar. Revista da STAB, v. 17, n. 1, p. 32-34, 1999.

INSTITUTO BRASILEIRO DE GEOGRAFIA E ESTATÍSTICA (IBGE). Sistema IBGE de recuperação automática - SIDRA. 2015. Available at: <http://www. sidra.ibge.gov.br/>. Acess on: 19 May 2016.

IQBAL, M. An introduction to solar radiation. Ontario: Academic Press Canadian, 1983.

JACKSON, R. D.; HUETE, R. A. Interpreting vegetation indices. Preventive Veterinary Medicine, v. 11, n. 1, p. 185200, 1991.

KEATING, B. A. et al. Modeling sugarcane production systems. Field Crops Research, v. 61, n. 3, p. 253-271, 1999.

LATORRE, M. et al. Correção atmosférica: conceitos e fundamentos. Espaço e Geografia, v. 5, n. 1, p. 153-178, 2002.

LIU, W. T. H. Aplicações de sensoriamento remoto. Campo Grande: Uniderp, 2007.

LUCAS, A. A.; SCHULER, C. A. B. Análise do NDVI/ NOAA em cana-de-açúcar e Mata Atlântica no litoral norte de Pernambuco, Brasil. Revista Brasileira de Engenharia Agrícola e Ambiental, v. 11, n. 6, p. 607-614, 2007.

MONTANDON, L. M.; SMALL, E. E. The impact of soil reflectance on the quantification of the green vegetation fraction from NDVI. Remote Sensing of Environment, v. 112, n. 4, p. 1835-1845, 2008.

NASSIF, D. S. P. et al. Parametrização e avaliação do modelo DSSAT/CANEGRO para variedades brasileiras de cana-de-açúcar. Pesquisa Agropecuária Brasileira, v. 47, n. 6, p. 311-318, 2012.

PEREIRA, A. R.; ANGELOCCI, L. R.; SENTELHAS, P. C. Agrometeorologia: fundamentos e aplicações práticas. Guaíba: Livraria e Editora Agropecuária, 2002.

PICOLI, M. C. A. et al. Índice de vegetação do sensor MODIS na estimativa da produtividade agrícola da canade-açúcar. Bragantia, v. 68, n. 3, p. 789-795, 2009.

RUDORFF, B. F. T. et al. Studies on the rapid expansion of sugarcane for ethanol production in São Paulo State (Brazil) using Landsat data. Remote Sensing, v. 2, n. 4, p. 1057-1076, 2010.

RUDORFF, B. F. T.; BATISTA, G. T. Yield estimation of sugarcane based on agrometeorological-spectral models. Remote sensing of Environment, v. 33, n. 3, p. 183-192, 1990.

SCARPARI, M. S.; BEAUCLAIR, E. G. F. Variação espaço-temporal do índice de área foliar e do Brix em cana-de-açúcar. Bragantia, v. 67, n. 1, p. 35-41, 2008.

SCHULTZ, B. et al. Self-guided segmentation and classification of multi-temporal Landsat 8 images for crop type mapping in southeastern Brazil. Remote Sensing, v. 7, n. 11, p. 14482-14508, 2015. 
SILVA, S. C. Informações meteorológicas para pesquisa e planejamento agrícola, referentes ao município de Santo Antônio de Goiás, GO, 2012. Santo Antônio de Goiás: Embrapa Arroz e Feijão, 2014.

SILVA, T. G. F. et al. Biometria da parte aérea da cana soca irrigada no submédio do Vale do São Francisco. Revista Ciência Agronômica, v. 43, n. 3, p. 500-509, 2012.

SUGAWARA, L. M.; RUDORFF, B.F. T.Acompanhamento do crescimento vegetativo da cana-de-açúcar por meio de séries temporais de NDVI do sensor MODIS. In: SIMPÓSIO BRASILEIRO DE SENSORIAMENTO REMOTO, 15., 2011, Curitiba. Resumos... São José dos Campos: INPE, 2011. p. 391-398.

TERUEL, D. A.; BARBIERI, V.; FERRARO JÚNIOR, L. A. Sugarcane leaf area index modeling under different soil water conditions. Scientia Agricola, v. 54, special n., p. 39-44, 1997.

TURNER, D. P. et al. Relationships between leaf area index and Landsat TM spectral vegetation indices across three temperate zone sites. Remote Sensing of Environment, v. 70, n. 1, p. 52-68, 1999.

UNITED STATES GEOLOGICAL SURVEY (USGS). Landsat 8. 2013. Available at: <http://landsat.usgs.gov/ landsat8.php>. Acess on: 10 Mar. 2015.

VILLA NOVA, N. A. et al. Estimativa de graus-dia acumulados acima de qualquer temperatura base, em função das temperaturas máxima e mínima. Caderno de Ciências da Terra, n. 30, p. 1-8, 1972.

WATSON, D. J. Comparative physiological studies on growth of field crops: I. Variation in net assimilation rate and leaf area between species and varieties, and within and between years. Annals of Botany, v. 11, n. 1, p. 41-76, 1947.

WIEGAND, C. L. et al. Vegetation indices in crop assessments. Remote Sensing of Environment, v. 35, n. 2-3, p. 105-119, 1991.

XAVIER, A. C.; VETORAZZI, C. A. Monitoring leaf area index at watershed level through NDVI from Landsat-7/ ETM+ data. Scientia Agricola, v. 61, n. 3, p. 243-252, 2004. 